\title{
Glacial lakes and its expansion in the north-central Bhutan and Kulha Kangri massif, Eastern Himalaya
}

\author{
J iro Komori†*, Syuji Iwata†, Deo Raji Gurungł and Hironori Yabuki§ \\ † Department of Geography, Tokyo Metropolitan University, Tokyo,192-0397, JAPAN \\ $\ddagger$ Department of Geology and Mines, Ministry of Trade and Industry, PO Box 173, Thimphu, BHUTAN \\ $\$$ Frontier Observational Research System for Global Change, Kanagawa, 236-0001, JAPAN
}

* To whom correspondence should be addressed.E-mail: jkomori@comp.metro-u.ac.jp

\begin{abstract}
A great number of the glacial lakes have appeared in many mountain areas of the world during the last half-century due to global warming. Severe floods have been caused by frequent outbursts from the glacial lakes. These glacial lake outburst floods (GLOF) have also occurred in the Himalayan mountains (e.g., Vuichard and Zimmermann 1987, Xu and Feng 1994), including Bhutan Himalaya. The last outburst flood in Bhutan, which originated from Lugge Glacial Lake in October 1994, caused damage to property along the river with the loss of more than 20 lives (Watanabe and Rothacher 1996). Hence, investigation of the glacial lakes is necessary for disaster prevention in Bhutan and the downstream region. Geological Survey of Bhutan (1999) and Mool et al. (2001) made the inventory of the glaciers and glacial lakes in Bhutan. Ageta et al. (2000) and Komori et al. (2003) obtained the expansion records of the lakes in Bhutan. However, much remains to be established about the spatial and temporal variation of glacial lakes not only in Bhutan but also the other Himalayan mountains. The present study revealed the current condition of glacial lakes and its secular variations during the last 45 years.
\end{abstract}

\section{Study area and method}

The study area is focused in the north-central Bhutan and Kulha Kangri massif, border region of Tibet which are the headwater of Chamkhar Chhu (river) and Kuri Chhu (lat. 27059'-28²4' N, long. $90^{\circ} 28^{\prime}-91^{\circ} 10^{\prime} \mathrm{E}$ ), the upper streams of the Manas river system. Distribution and development history of the lakes is revealed from detail tracing by the image-editing program (Deneba Canvas 9), using digitized two CORONA satellite imagery (about $10 \mathrm{~m}$ digitized resolution, taken in 1967 and
1968), two Landsat satellite imagery (normal resolution of $30 \mathrm{~m}$, taken in 1990 and 2000) and three SPOT satellite imagery (nominal resolution of 10 - 20 m, taken in 1991, 1993 and 2001). The Indian toposheets $(1: 50,000$ in scale, based on aerial photographs taken in 1956 and 1958) and the Soviet toposheets (1:200,000 in scale, based on aerial photographs taken from 1972 to 1974) were used for geometric correction. The field investigation in Chamkhar Chhu was carried out in late September 2002, with the cooperation of the Geological Survey of Bhutan.

\section{Results and discussion}

More than twenty glacial lakes, located on the surface or front of the glacier in the headwater of Chamkhar Chhu and Kuri Chhu are recognized. In particular, detail observation was carried out for 19 potentially hazardous lakes which are large and expanding water area, and showing dangerous situation. The observation provided important and previously unknown information. The serial number of hazardous lakes in Chamkhar Chhu and Kuri Chhu basin were given as CGL-1, 2, 3, and KGL-1, 2, 3, tentatively. The summarized features of these lakes as follows:

(1) Lake area: Maximum area of hazardous lakes is $1.70 \mathrm{~km}^{2}$ (KGL-13, Figure 1). Besides, three lakes area are over $1 \mathrm{~km}^{2}$.

(2) Expansion rate: Figure 2 showing the expansion rate of the lake area in the southern and northern side of the Himalaya. The largest expanding lake in Chamkhar Chhu and Kuri Chhu basin shows highly expansion rates of $0.027 \mathrm{~km}^{2} / \mathrm{y}$ (CGL-6, Chamkhar glacial lake) and $0.025 \mathrm{~km}^{2} / \mathrm{y}$ (KGL-13), respectively.

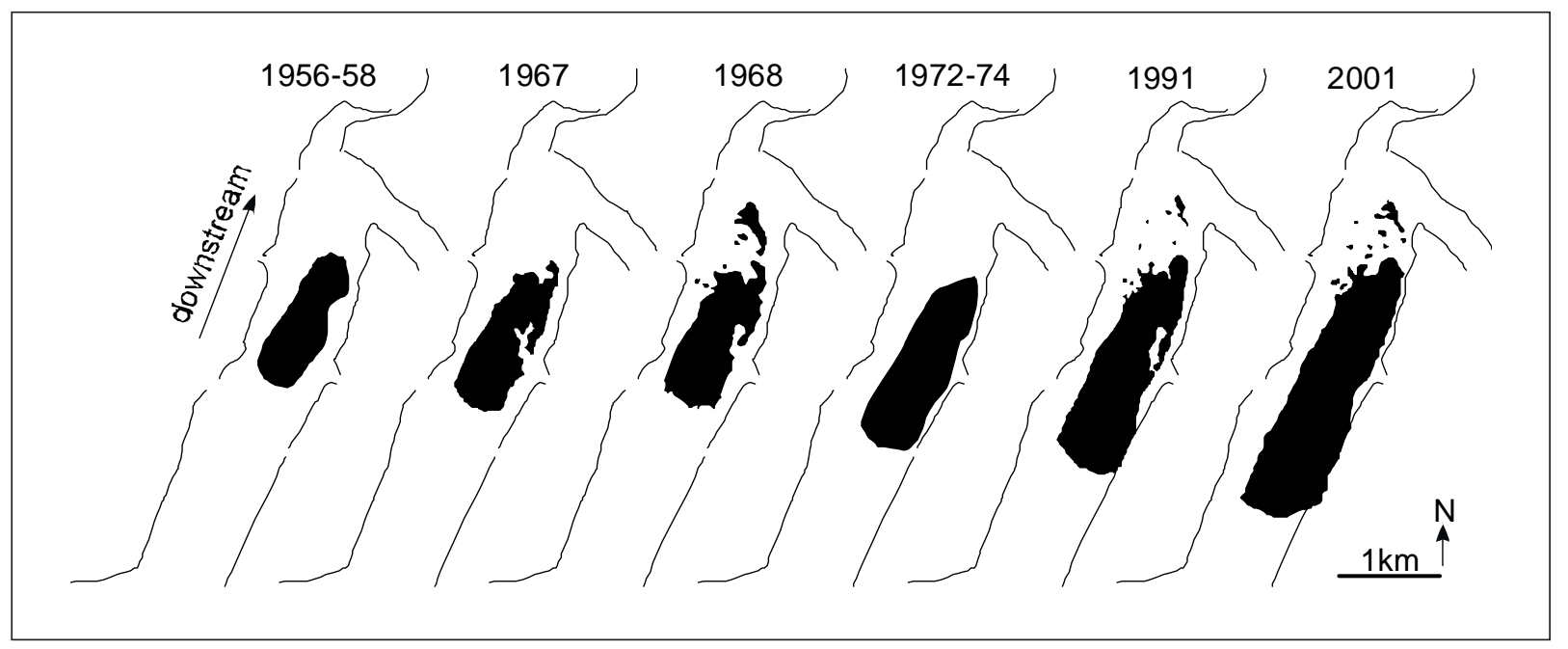

Figure 1. Area variation of KGL-13 from 1956-58 to 2001. Outer solid line is the outline of the glacier 


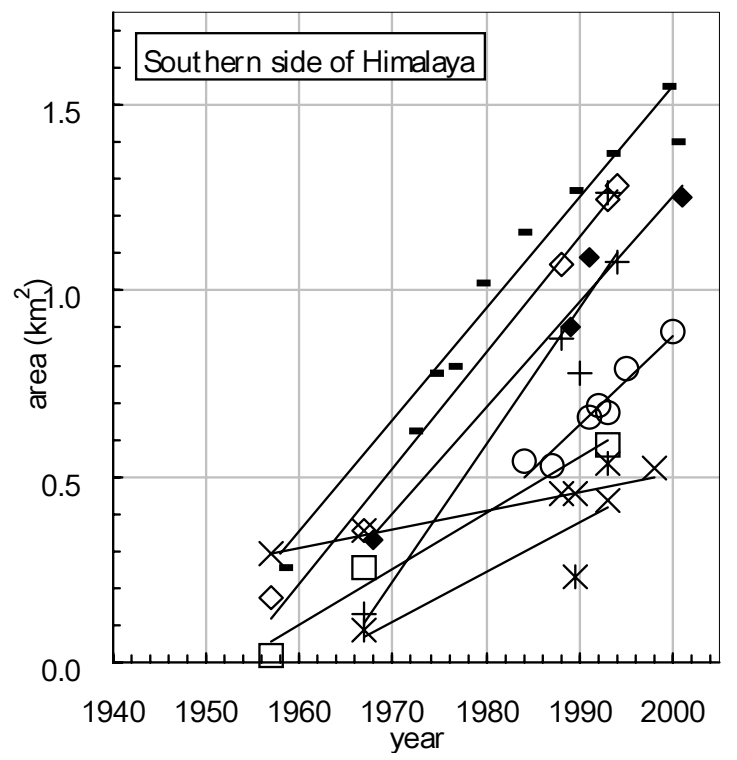

FIGURE 2. Expansion rate of the glacier

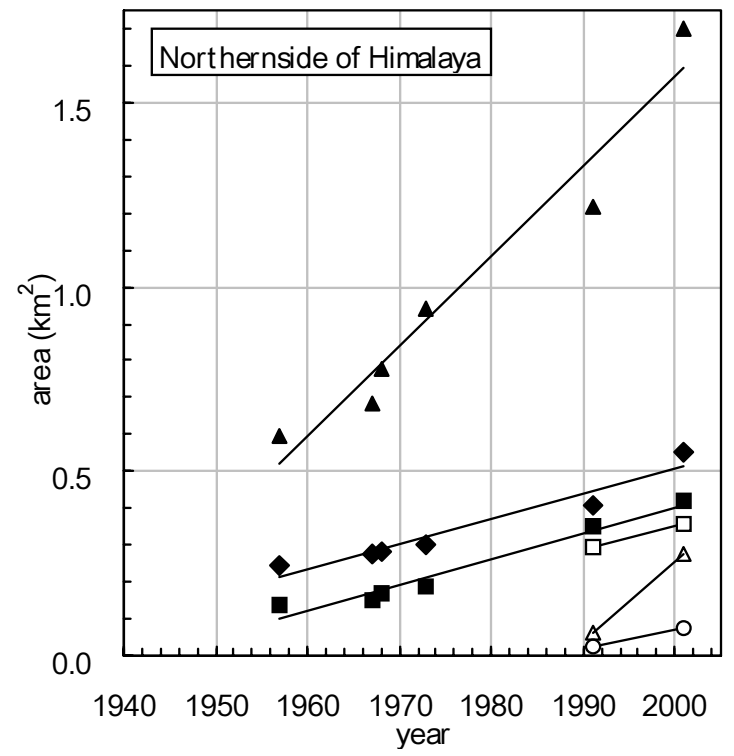

References

Ageta Y, S Iwata, H Yabuki, N Naito, A Sakai, C Narama and Karma. 2000. Expansion of glacier lakes in recent decades in the Bhutan Himalayas. Proceedings of the Seattle Workshop, 2000; Debris-Covered Glaciers. IAHS, Publication no. 264: 165-175

Geological Survey of Bhutan. 1999. Glaciers and Glacier Lakes in Bhutan. Geological Survey of Bhutan. $83 \mathrm{p}$

Komori J, DR Gurung, S Iwata and H Yabuki. 2003. Variation and lake expansion of Chubda Glacier, Bhutan Himalayas, during the last 35 years. Bulletin of Glaciological Research 21: 49-55

Mool PK, D Wangda, SR Bajrachaya, DR Gurung and SP Joshi. 2001. Inventory of glaciers, glacial lakes and glacial lake outburst floods, Bhutan. ICIMOD, Kathmandu. $247 \mathrm{p}$

Vuichard D and M Zimmermann. 1987. The 1985 catastrophic drainage of a moraine-dammed lake, Khumbu Himal, Nepal: case and consequences. Mountain Research and Development 7: 91-110

Watanabe T and D Rothacher. 1996. The 1994 Lugge Tsho glacial lake outburst flood, Bhutan Himalaya. Mountain Research and Development 16: 77-81

$\mathrm{Xu} \mathrm{D}$ and Q Feng. 1994. Dangerous glacier lakes and their outburst features in the Tibetan Himalayas. Bulletin of Glacier Research 12: 1-8

Yabuki H. 2003. Investigation for expansion of Imja glacier lake using satellite images. Meeting report of the Joint Research Program of the Institute of Low Temperature Science, Hokkaido University, 24-30 (In Japanese)

Yamada T. 1998. Glacier lake and its outburst flood in the Nepal Himalaya. Monograph No. 1, March 1998 Data Center for Glacier Research, Japanese Society of Snow and Ice. 96 p 
Right: in the southern side of the Himalaya. -:Tsho Rolpa, $\circ:$ Imja lake, $\diamond:$ Raphsthreng, $+:$ Lugge, ${ }^{*}$ : Thorthomi, $\square:$ Wackey, $\times$ : Mouzom, $\bullet:$ Chubda Left: in the northern side of the Himalaya. $\Delta:$ KGL-13, : KGL-9, $\bullet:$ KGL-12, $\Delta:$ KGL-11, $\circ:$ KGL-10, $\square:$ KGL-12 The plots of Fig 2-b and Chubda glacial lake are based on this study. Tsho Rolpa and Imja were reffered form Yamada et al.(1998) and Yabuki (2003), respectively. The othe data are digitized and measured from the figures in Ageta et al. (2000) 